\title{
Employment Creation and Extreme Poverty Eradication through Open and Distance eLearning and Technical-Vocational Education and Training in Zimbabwe
}

\author{
Betty Kutukwa Mutambanengwe \\ Materials Development Unit, Zimbabwe Open University, \\ bmutambanengwe@gmail.com \\ Ignatius Isaac Dambudzo \\ Faculty of Arts and Education, Zimbabwe Open University \\ idambudzo@yahoo.co.uk
}

\begin{abstract}
This study explored how Open and Distance eLearning (ODeL) system is enhancing employment creation and extreme poverty eradication in Zimbabwe. Poverty is a challenge in developing countries in the presence of unemployment and lack of education. This study aimed to put into perspective the strides made by ODeL institutions in Zimbabwe towards extreme poverty eradication through TVET in the education system. Data were collected from purposively selected 20 ODeL graduates including; entrepreneurs, street vendors, and individuals, formally and informally employed, by using interviews and observation, in this case study. The study employed thematic analysis for the narrative qualitative data. The study revealed that poverty can be reduced through skills empowerment to learners at all educational levels. Exposure to a bouquet of vocational subjects in technical-vocational institutions has enabled entrepreneurs to create employment, applying acquired skills. The major barriers to effective entrepreneurship and employment creation were the scarcity of resources and natural disasters. The study is also significant that educational planners and policy-makers may formulate policies that encourage school and college graduates to be innovative, self-reliant, and may guard against extreme poverty in their communities. It can be concluded that possession and application of vocational skills may create employment and eradicate extreme poverty. It is, therefore, recommended that TVET starts early in life for innovativeness and effective use of available resources. Further research could be carried out on the nature of programmes in learning institutions that empower learners with skills for employment creation, sustainable development, and extreme poverty eradication.
\end{abstract}

Keywords: Technical-Vocational Education and Training, Employment creation, Entrepreneurs, Poverty, Street vendor

\section{Introduction}

In most developing countries, particularly in Zimbabwe, poverty is still a challenge. Poverty eradication seems a far-fetched aim of the millennium development goal number one, which states, 'Eradicate extreme poverty and hunger' (The World Bank, 2017), due to varied challenges brought about by high unemployment rate and natural disasters. Some of the natural disasters which hit hard developing countries include; floods, drought, earthquakes, landslides, hurricanes, volcanic eruptions, tsunamis, forest fires, the destruction of crops by locusts, wild animals, or army-worm; heat waves and epidemics which are beyond human control. However, there are a variety of strategies at the disposal of policy-makers and educationists, such as making 
use of Open and Distance eLearning (ODeL) institutions to impart lifelong skills to the labour force to enable them to make a living from the resources at their disposal. For instance, Zimbabwe Open University (ZOU) offers degree and non-degree programmes through ODeL to willing and able learners who qualify to further their studies at their own pace. Other tertiary institutions in the country are offering programmes on what they term 'Block Release' weekend and evening classes mode of teaching and learning, emulating the ZOU's teaching/learning system to enable learners to earn while learning in the comfort of their homes and workplaces.

Empowered with the right technical-vocational skills, graduates brace themselves to venture into the world of work to earn a living thereby reducing poverty and hunger and improve on their lifestyles and economic status.

\subsection{Statement of the Problem}

Extreme poverty is a serious global problem that has an impact on education and development particularly in developing countries like Zimbabwe. The problem that the study sought, was to understand why, how, and to what extent Open and Distance eLearning Institutions employ TVET to impart life-skills that contribute towards the eradication of extreme poverty in third world countries, with specific reference to Zimbabwe.

\subsection{Aim and Objectives of the Study}

The research study aimed to put into perspective achievements made by ODeL institutions in Zimbabwe towards extreme poverty eradication through TVET. The objectives of the study were to:

i) establish the employment creation success stories of ODeL and TVET graduates in Zimbabwe

ii) determine participants' views on the role of ODeL and TVET institutions in eradicating extreme poverty and hunger in Zimbabwe

iii) determine the impact of ODeL and TVET on employment creation.

iv) make recommendations for policy-makers and educationists on strategies of overcoming challenges of eradicating extreme poverty in Zimbabwe

It is hoped that the achievement of these objectives would help to highlight the strides made by ODeL institutions and many more strategies towards the eradication of extreme poverty and hunger, not only in Zimbabwe, but in other developing countries in the world and specifically in the SADC region.

\subsection{Significance of the Study}

The study has the potential to benefit several groups of stakeholders that include; educational planners and policy-makers, when they formulate and implement policies that encourage the Zimbabwean populace to enrol in TVET institutions and become self-reliant and guard against extreme poverty. The consumers of the well-crafted poverty eradication policies, thus the general public are bound to benefit through the exposure to career opportunities, strategies for poverty eradication, employment creation, entrepreneurship, and socio-economic development programmes. 


\section{Background of the Study}

Zimbabwe, as a developing country in the Southern African Development Community (SADC), is faced with one of the worst challenges of poverty, despite the country being rich in natural resources. The situation is exacerbated by the fact that Zimbabwe is a land-locked country that depends on other countries' ports for imports and exports of its goods. The Millennium Development Goals Report (2014, p. 4) states that about one out of five people in developing countries survives on less than $\$ 1.25$ per day (ZIMSTAT, 2015). Zimbabwe is riled with a range of challenges and this study focuses on the challenge of poverty propelled by unemployment. According to the Millennium Development Goals Report (2014), poverty is the lack of conveniences and the amusements of human life. In other words, people who are classified as being poor are those who are not educated and not employed. They lack health care, means of transport, adequate or proper clothing and shelter. In addition, the poor in developing countries also lack adequate food to sustain physical and mental health, resulting in their level of alertness at school and work, being affected. This translates to what extreme poverty is about.

In times of severe drought in Zimbabwe, the rural people suffer the most as they lack financial and material resources for survival, only resorting to eating wild fruits, such as Governor's plum (nhunguru), Mobola plum (hacha), Corky monkey orange (matamba), Strychnospungens (matufu), Simple spinednum-num (nzambara), Rhuslancea (masokoziana), Bird plum or African sweets (nyii), Monkey bread (masekesa), Snot apple (matohwe), Wild grape (tsambatsi), Ziziphusabyssinica (masau), Sour plum (tsvanzva/nhengeni), Smelly-belly finger leaf (tsubvu), Garcinia buchananii (matunduru), and Prickly pear (madhorofiya). According to Goredema (2018), these are some of the edible wild fruits and wild berries from those trees which can still produce fruit under climatic stress, such as drought in some regions in Zimbabwe, especially Manicaland, an Eastern Province in Zimbabwe. These wild fruits in some areas were not adequate as humans were competing with livestock and making other people resort to cooking unripe fruits, such as pawpaws, to feed their families, because food aid from Non-Governmental Organisations was not enough for everybody in need. Thus, trees and forests are supplementing people's diets in the absence of food crops during drought periods like the 2015-2016 Zimbabwe's agricultural period.

In urban areas, where there are no wild fruits, life is tougher for child-headed families and elderly, who are too weak and old to compete for resources, in the environment with the young and educated. It means the poor go for days surviving on porridge, alternating it with boiled green vegetables, an observation made by the researcher in one of the high-density suburbs in Harare, Zimbabwe in 2015. However, according to United Nations Sustainable Development Goals (2015), afforestation and food production contribute to global change and food security and are likely to end hunger, if policies are effectively implemented and available food is equitably distributed.

According to the World Bank (2017), to eradicate extreme poverty, a nation requires a strong economy that produces jobs and appropriate salaries; good governance; with good infrastructure and service provision, including schools, hospitals, roads, food security, and energy. Countries need healthy and well-nourished children, who are the future human capital, that will lead and fuel economic growth. On the other hand, the ILO (2015) argues that in the world of 
work, the jobs on the market should be quality jobs for them to be key drivers for development, but where technical-vocational training is mainly provided outside the formal school system, monitoring and evaluation of the quality of workmanship becomes difficult. An example is that of places like Glen View Home Industry in Harare, Zimbabwe, and other such places in other towns and cities, as well as growth points, where skills are learned informally through on-the-job training offered to the employees. Therefore, because this kind of training is not documented, then it becomes difficult to determine the percentage of their contribution to employment creation and extreme poverty eradication. The exception is that, the general public can observe people in such communities, not starving and the crafts made, flooding the streets, as well as some hardware shops and homes both in cities and rural areas. Thus, to make achievements in extreme poverty eradication, entrepreneurs should be given adequate financial and material support, for sustainable socio-economic development.

However, Zimbabweans have displayed great ingenuity when it comes to survival skills in the informal sector, such as creating jobs for themselves as carpenters, street-vendors, cross-border traders, tinsmiths, hairdressers, florists, commuter omnibus rank-marshals, emergency taxi drivers (mushika-shika), dress-makers, upholsterers, sculptors or brick-moulders among others. These jobs have kept many people in employment (mostly informal employment), and thus have helped to avoid high open unemployment and extreme poverty as viewed by developed countries, despite adverse economic conditions, currently being experienced by the majority of Zimbabweans. But the informal sector is not always recognised by the law, yet that is where the money is (microeconomics), which keeps people out of extreme poverty and the nation ticking. Thus, most informal workers find themselves on the fringes of the law as they often lack the required licenses, or violate zoning by-laws that ban commercial activity from residential areas, and city streets (Luebker, 2008).

To the street vendors, these by-laws were introduced by the local government in a deliberate attempt to keep cities clean and to protect shop owners' businesses (Supplement to the Zimbabwean Government Gazette dated the 19th June, 2020). Yet, on the other hand, indigenisation and youth empowerment are being encouraged in the name of Zimbabwe Agenda for Sustainable Socio-Economic Transformation, which was meant to guide and direct all government policies and programmes to accelerate economic growth and wealth creation. The Zimbabwean Government hoped to achieve the development agenda goals through taping the human and natural resources of the country and channelling them towards economic and sustainable development to improve the livelihoods of the Zimbabwean citizens. However, the success of the development agenda goals will depend on several factors to include, most probably the provision of TVET to all those willing and able learners as well as aspiring entrepreneurs, and funding in the form of soft loans to kick-start projects to boost employment levels.

According to Rouse (2015), ODeL is a general term for the use of telecommunication to provide or enhance learning. The learners do not have to be in the same room with the tutor, but can learn while in the comfort of their homes or workplaces. Around the world, the academic community is discovering and exploring the Internet, teleconferencing, and related means to achieve an extended classroom or learning experience. ODeL is an opportunity of giving a second chance to those who failed to gain entry into conventional learning institutions including TVET, which can also be provided informally. 
Empowered with the right technical-vocational skills, youths and aspiring entrepreneurs find themselves in a position to venture into the world of work to earn a living thereby reducing extreme poverty and hunger. An entrepreneur in this context; is a person who starts his/her own business or assists others in a business venture. He/she is someone who is not afraid to take major risks and wants to add value to the world. He/she is someone who can plan; communicate; market; and possesses basic management, interpersonal, and leadership skills (Brooks, 2015). In other words, an entrepreneur is an agent of change, for example, the development of new products can create employment and the livelihoods of the employees would eventually improve resulting in socio-economic development and eradication of extreme poverty. Hence, the purpose of this study was to identify gaps and come up with strategies that educational planners, policy-makers, and other stakeholders would employ in the hope of achieving Millennium Development Goal Number One; that of seeing extreme poverty eradicated not only in Zimbabwe but in other developing countries as well.

\subsection{How Poverty is Viewed in Society}

Poverty is defined as a phenomenon or broad concept encompassing lack of or low income or consumption; geographical isolation; lack of assets or having little or poor-quality land, housing, livestock, or other productive assets. Poverty also includes having to live in a polluted or hazardous environment; having little or no education; having poor health, always suffering from illnesses of various kinds; experiencing powerlessness, and being excluded from decisions that have an impact on one's life (McCullock, Winters \&Cirera, 2001). In other words, poverty is a serious global problem that has an impact on education and development. It is a multi-dimensional phenomenon, with varied forms which, according to economists, include: hunger and malnutrition, limited access to education and other basic services, social discrimination and exclusion as well as the lack of participation in decision-making (United Nations, undated).

The World Bank Organization (2009) in Government of New Brunswick (2015) also describes poverty as hunger, lack of shelter, poor health, lack of education, being illiterate, being unemployed, living from hand-to-mouth, having no voice on issues that affect the individual and not protected from violence. This implies that being poor limits what a person can and cannot do both in terms of immediate and future actions because poverty is about not having enough money to meet basic needs including food, shelter, and clothing. In essence, the World Bank sums up poverty as individuals lacking in three key areas: opportunity, security, and empowerment. Therefore, in a developing country like Zimbabwe, where there are abundant natural and human resources, which if well managed; extreme poverty eradication would be possible to a certain degree provided it is one of the priorities on the national policies and actions agenda, in addition to employment creation and provision of education to all.

\subsection{Street Vending and Extreme Poverty Reduction}

A street vendor, in this context, is someone who promotes or exchanges goods or services for money. In other words, street vending is the act of selling goods on the streets for a living particularly in urban areas. According to Women in Informal Employment: Globalizing and Organizing (WIEGO) (2015, p. 1), 
Street vendors are an integral part of urban economies around the world, offering easy access to a wide range of goods and services in public spaces. They sell everything from fresh vegetables to prepared foods, from building materials to garments and crafts, from consumer electronics to auto repairs and to haircuts.

This is a common sight in urban areas in developing countries including Zimbabwe particularly in the streets of Harare. Therefore, to get this far, what role has ODeL type of education played in reducing extreme poverty in the developing world?

The United Nations (undated) posits that poverty is linked to unemployment and underemployment. Many people enter into street vending because they cannot find employment in the formal economy. This is because, for the poor, labour is the major and only asset they can use to improve their well-being. To most poor families, lack of necessities forces them to employ child labour to boost their meagre incomes by working as domestic workers in urban areas, farm labourers, as well as engage in illegal mining,s which results in environmental degradation, further aggravating poverty conditions. Hence, the creation of productive employment opportunities is essential for achieving extreme poverty reduction and sustainable economic and social development. This is what Zimbabwe is aiming for by allowing street vendors, who are microentrepreneurs, to sell their wares at designated places. However, some street vendors choose to sell their wares in some undesignated areas, so, when it comes to fruits and vegetables, it becomes a health hazard to the unsuspecting clients who buy and consume these fruits and vegetables (Supplement to the Zimbabwean Government Gazette dated the 19th June, 2020). But surviving as a street vendor requires a certain amount of skills. Competition among vendors for space in the streets and access to customers is strong in many cities, especially after hours, when most of the shops will have been closed. Vendors must be able to negotiate effectively with wholesalers and customers (must possess good communication skills) as evidenced by the way they entice customers to buy their wares. They should also be prepared to put up fistfights with thieves and other rude vendors for survival on the streets.

Despite the challenges, street trade can offer a viable livelihood, even though earnings are low and risks are high for many vendors, especially those who sell fresh fruits and vegetables (Roever, 2014). Having an insecure place of work is a significant problem for those who work in the streets. Lack of storage space, theft, or damage to stock, are common issues encountered daily by the poor. An example is the loss of wares belonging to street vendors which were gutted by fire at an undesignated and unsafe storage space in Harare on 9 July 2015 (Samukange, 2015). In addition, by-laws governing street trade can be prohibitive and license is not only hard to get but costly, leaving many street vendors vulnerable to harassment, confiscations, thefts, and evictions. On the other hand, Jaishankar and Sujatha (2016) posit that street vendors face many challenges that include the lack of protection from government and labour laws, and their profits are very low. At times vendors pay bribes to municipal police to continue operating. Their activities are unhygienic and therefore, are always blamed for any disease outbreaks. Surprisingly, their contribution to socio-economic well-being is not recognised by the government, and yet in essence their activities may be termed micro-economics. Street vendors' profession is considered illegal, yet the unemployment rate in the country is very high compared to that of other countries in the SADC region (SADC, 2018). Therefore, they are always on the wrong side of the law even though that they are trying to make an earnest living for their families. 
Policy-makers and entrepreneurs need to provide decent and gainful employment that empowers the poor, especially the youth, our future generation, who are tomorrow's leaders and economists. In the same vein, economists argue that rapid economic growth can potentially bring a high rate of expansion of productive and remunerative employment, which can lead to a reduction in extreme poverty and result in sustainable socio-economic development. However, the contribution of the growth process to extreme poverty reduction does not depend only on the rate of economic growth which depends on available and accessible natural and financial resources, but also on the ability of the poor to respond to the increasing demand for labour in the more productive categories of employment.

\subsection{Impact of Poverty on Teaching and Learning}

Ciaccio (2000) and Brophy (2000) in their studies, noted that lack of emotional nurturing which is absent in poor families can lead to feelings of alienation, inadequacy, depression, and anxiety. Aggressive or impulsive behaviour and social withdrawal can also result. Among such learners, emotional security and self-esteem are often lacking. There is a craving for attention and a need to belong. Usually, these learners end up displaying unacceptable behaviour so that they are noticed. The learners from poor backgrounds may have no real personal goals or vision, due to lack of exposure, but only fantasies of what they hope for. Slavin (1998) points out that, learners from poverty-stricken families start in life at a disadvantage, due to their status and socio-economic position in the community. Their mothers may also have no or inadequate prenatal care. Usually, they may have insufficient early health care. If the parents are fortunate to have jobs, the type of learning institutions their children attend may be of poor quality churning out knowledge-hungry graduates.

Additionally, poor children do not have the same kind of experiences that children of other social classes do. It has been observed by psychologists that the experiences, learners from poor families miss out on are those that could help in the development of skills and academic achievement due to exposure and practice. For example, today in well-to-do families, a computer with an Internet connection where they can Google answers to general questions, read current news, play educational games; a television; a cellular phone for every member of the family, and many other gadgets cannot be missed. While in a poor family, owning such would be a far-fetched wish or dream. Because of hunger and poor health, learners from poor families find it difficult to fully participate in class, unless they are naturally intelligent, and therefore are at a disadvantage from birth as emphasised by Slavin (1998). These sentiments are also supported by Dambudzo (2016) who points out that poverty always impacts negatively on learning, development, and livelihoods of particularly the marginalised groups in most developing countries including Zimbabwe.

\subsection{Extreme Poverty Eradication}

Poverty eradication refers to the permanent ending of the existence of poverty in a community or a country. The United Nations Department of Economic and Social Affairs Division for Social Policy and Development (2015) argues that a sure way of eradicating extreme poverty would be to empower people by giving them a good vocational education. The right education will help enlighten people and prepare them to have a career or be employable and to hold a job that 
will make them more confident. The right education gives individuals the chance to learn from others and allows them to earn a good living to help them look after their families leading them to live a better life. UNESCO (2013) posits that a good educational foundation boosted with skills from TVET institutions will not just be preparation for work for a country's youth, but it is also preparation for life as the skills acquired are vital for extreme poverty reduction, economic recovery, and sustainable development. A good educational foundation also promotes critical thinking and encourages behaviour change in any society. In other words, poverty alleviation programmes in TVET institutions aim to reduce the incidence of poverty in a more sustained way than poverty relief programmes, which give short-term assistance to people who are living in poverty. People with skills become self-employed and if they have adequate resources, they end up being employers themselves, sharing financial resources indirectly.

\section{Research Design and Methodology}

This was a case study of ODeL graduates including those individuals in formal and informal employment, entrepreneurs, and street vendors. A qualitative methodology guided by the research objectives (Neuman, 2014), was employed to get a deeper understanding of how ODeL has impacted the livelihoods of Zimbabweans in general. With this method, participants were not restricted to pre-formulated questions, but they were also able to qualitatively express themselves freely. The method allowed the researchers, to probe for more information and clarification of issues through observing, interacting with participants, and interviewing them (Alzheimer Europe, 2013).

\subsection{Population and Sample}

The target population for this study was drawn from those individuals in employment who acquired additional educational qualifications through ODeL, entrepreneurs, and street vendors. Twenty (20) participants were purposively sampled targeting those rich in data specific to this study to include school heads (5), university lecturers (6), chief secretaries (2), entrepreneurs (2), and street vendors (5). Individuals who are in formal employment and entrepreneurs were targeted because they have a story to tell about how ODeL has changed their livelihoods. Meanwhile, street vendors were randomly sampled and were found to be in a position to express how they were managing to reduce extreme poverty in their families and community, employing TVET skills they possess. The study was confined to Harare, the capital city of Zimbabwe for convenience, where participants were likely to provide meaningful answers to questions and suggest possible solutions to the problem of poverty and unemployment.

\subsection{Research Instruments for this Study}

The main instruments for data collection in this study were the face-to-face interviews, the researchers' field notes of personal observations and informal conversations confirmed information from interviews. Triangulation of instruments, which according to Johnson and Christensen (2014) is the combination of at least two or more theoretical perspectives, methodological approaches, data sources, and analysis methods, were used to counterbalance the deficiency of a single strategy, thereby increasing credibility, validity, and reliability of results. 


\subsection{Data Analysis}

The study employed thematic analysis, which is much more than simply summarising the data as a way of interpreting and making sense of the qualitative data gathered from informants. The themes emerged from the aim and objectives and semi-structured interview questions, for example, the impact of poverty on education, the role of ODeL institutions, success stories of ODeL graduates, and challenges faced by entrepreneurs and street vendors.

\section{Limitation to the Study}

The limitations to this study were that some participants were not forthcoming with information due to interfering factors such as the presence of the researcher. Others, particularly street vendors, did not want to be interviewed due to other interfering factors, such as the political climate and not wishing to be disrupted from their businesses, and therefore, could not participate. However, since Harare streets are congested with street vendors, the researchers approached those who were willing to be interviewed and, in some instances, the researchers ended up buying some of the items being sold on the street to win their trust.

\section{Findings and Discussions}

In response to the question on how the participants benefited through ODeL, the response of one self-employed man among the interviewees was: Had I not acquired further education through ZOU, I could still be working in fields in my rural home. In other words, these participants meant that ODeL had greatly improved their livelihoods in that, had they not acquired further education through ZOU, $80 \%$ of these participants who are in formal employment could still be toiling in their rural homes with no income and poor harvests to feed their families. Participants also cited that without the kind of education afforded to them through ODeL, the majority of these participants could be part of the statistics among the world's poor. ODeL has broadened the participants' way of thinking and exposure to what is happening in their environments and the world at large. For example, one participant had this to say: With the additional qualifications, I can now confidently compete with other colleagues on the job market and I am no longer as poor as I was before. That was a comment from one of the Chief Secretaries interviewed. This is a clear indication that education has helped the majority of the participants to refine their skills so that they can now confidently compete in the world of work.

In addition, $70 \%$ of the participants cited that they have also secured decent jobs, such as being Chief Executive Officers of well-known companies as well as being University Lecturers, Chief Secretaries of institutions, and Heads of Schools among others. For example, one school head had this to say: I was an ordinary classroom teacher, but now I am the Head at this school due to the additional qualifications I acquired at ZOU. I am well respected in the community and my family is now enjoying the fruits of my additional qualifications. It pays to go to school.

Responses from $83 \%$ of the interviewees, thus the school heads, entrepreneurs, and street vendors revealed that education ensures an appropriate understanding of poverty, its causes, and possible ways of eradicating extreme poverty. For example, one School Head said: If you compare an educated person and one who never went to school, the way they try to solve problems is quite 
different because an educated person, if he/she is widely read, he or she can compare how other people in other countries are handling the poverty menace and see what may work for own situation. Educated people can weigh pros and cons of most situations including employment creation before acting. This is an indication that the reasoning capacity of an educated person is, in general, not limited. They can see beyond the confines of their environment and this is also echoed by The United Nations Department of Economic and Social Affairs Division for Social Policy and Development (2015), who posit that empowering people by giving them a good vocational education ensures extreme poverty eradication and employment creation.

One entrepreneur said: The TVET skills I acquired in college have made me what I am today and I can employ others even though my business is still small. If I happen to get funding to expand, I will employ more people with skills as they do not need further training and poverty will be a thing of the past in our community. To this entrepreneur, the limiting factor to his upcoming business is funding otherwise with the skills he possesses, the sky is the limit and extreme poverty can easily be eradicated if the work environment is conducive.

However, $17 \%$ of the interviewees, comprising street vendors out-rightly expressed that: In these economic hardships, whether you are an educated graduate from university or not, we are all poor competing to sell tomatoes, second-hand clothes, and airtime on the streets. To these street vendors, possession of educational qualifications is of little value because of the high rate of unemployment being experienced in Zimbabwe today in 2020.

Interviews with participants also revealed that ODeL has benefited the interviewees in many ways to include the following:

One university lecturer said: Some organisations, for instance, the Zimbabwe Open University, Zimbabwe School Examinations Council, and many others pay tuition fees for ODeL programmes for staff development of their employees, thus, making the employee advance academically without further eroding the meagre family income.

One of the School Heads, proudly said: With ODeL, individuals are afforded a second chance to learn while they earn, realising their dreams where doors would have been closed where they intended to pursue education the conventional way. In other words, there is brain gain as the individual applies the theories and skills, he/she has learned as he/she executes daily duties. For example, instead of an ordinary classroom teacher crossing the border to go and do menial work in neighbouring countries like South Africa or any one of the developed countries, the teacher upgrades him/herself academically and is promoted to headship, an administrative position. Thus, the individual's status, and lifestyle change.

One entrepreneur revealed that: There is no age limit and the sky is the limit for those willing and able learners who can eventually become consultants in addition to their formal employment or day-to-day activities. An example of the programmes pursued through ODeL, such as Psychology, exposes an individual to a wide range of employment opportunities on the market. For example, one can join the Human Resources Department of any organisation; Community Development under Non-Governmental Organisations (NGO), can work in institutions such as, hospitals or may be involved in Peer Education in schools.

With technical-vocational programmes, graduates are empowered with skills for indigenisation and entrepreneurship management leading them to eventually become employers themselves, reducing extreme poverty in the community. Since ODeL qualifications are 
recognised internationally, the holders become marketable and confidently compete in the world of work within and outside borders in addition to being promoted to managerial or administrative positions, where they lead by example, and make decisions based on widely read points of view. This implies that when one has acquired additional educational qualifications and is either promoted at their place of work or when their standard of living improves, they do not remain the same in society, instead they become a source of motivation to family members and others in their community.

One entrepreneur, when asked about the impact of TVET on employment creation said: ODeL has given leverage in areas that require higher qualifications, and build confidence in people like us venturing into opening small enterprises and contributing to extreme poverty reduction in the community. We entrepreneurs have managed to design instruments by borrowing ideas from, for example, the motor industry, do write meaningful reports using computers, and now understand and can curb forms of cheating, which is anti-progressive in any organisation. Otherwise, we were ignorant of management skills before advancing academically through ODeL.

On the other hand, even street vendors, who are entrepreneurs in a small way, are also using the basic knowledge they acquired both formally and informally to manage their wares and look after their families preventing them from plunging into extreme poverty. However, as echoed by Roever (2014), the street vendors cited that they were facing challenges encountered with lawenforcement agents, who were disrupting the smooth flow of their businesses. In some instances, vendors' goods are confiscated by the Municipal Police, which is a drawback, where someone is trying to earn an earnest living instead of indulging in unacceptable behaviour such as, pickpocketing, house-breaking, dealing in drugs, illegal gold-panning among others.

It also emerged that if learning institutions were well funded and well-staffed with qualified human resources, and have good infrastructure, education would empower individuals with technical-vocational skills, enhance innovativeness and critical thinking. A well-structured education system enables graduates to gainfully use available resources even though these resources are scarce, particularly in developing countries like Zimbabwe. However, with appropriate skills, Zimbabweans could achieve more since human and natural resources are in abundance (Tenebe, 2015). In addition, industrial attachment, which is a practical component requirement for every programme in both conventional and ODeL higher education, allows learners to experience real-life situations in the world of work.

\section{Conclusion}

It may be concluded from the findings that poverty is one of the major factors contributing to high unemployment, in developing countries, particularly in Zimbabwe. Poverty hinders employment creation and socio-economic development. But with ODeL, anyone with the potential to upgrade themselves academically and professionally, can make a remarkable contribution towards extreme poverty reduction in their family, community, country, and the region as a whole. With ODeL, willing and able individuals, can learn, earn and look after their families as echoed by The United Nations Department of Economic and Social Affairs Division for Social Policy and Development (2015). Indeed, ODeL as open education without boundaries has had a positive impact on extreme poverty reduction and employment creation in Zimbabwe and the world at 
large. Learners who could not enrol in conventional higher education institutions are given a second chance to acquire additional qualifications through ODeL, more so in this COVID-19 pandemic, where social distancing is said to be one of the precautionary measures to stay safe. It may also be concluded if learners are equipped with technical-vocational skills and funding, unemployment and extreme poverty could be reduced significantly. Even street vendors are just managing to look after their families, with the marginal profits, they make. Because they have acquired entrepreneurial skills through formal and informal education. Therefore, including TVET programmes in Open and Distance eLearning institutions, to impart life skills, will contribute to a greater extent, towards the eradication of extreme poverty in developing countries with specific reference to Zimbabwe.

\section{Recommendations}

In view of the above findings, it is recommended that: ODeL institutions develop more programmes in line with the requirements of the industry and community so that graduates are either self-reliant or employable. Learners should go through TVET starting early in life, so that innovativeness in making use of available resources, becomes part of their livelihoods. Entrepreneurship should be a compulsory course in primary, secondary, and tertiary institutions to build confidence in learners. Upon graduation, these graduates are capable of venturing into starting their businesses, thereby creating employment for themselves and others. Street vendors should be allowed to carry out their businesses without the fear of harassment by law-enforcement agents, until industries are revived and the economic situation in the country is improved. This is expected to absorb the workforce, reduce crime and eradicate extreme poverty in families and the community. Further research should be carried out on the nature of programmes, in learning institutions, that empower learners with innovative skills for sustainable development.

\section{References}

Alzheimer Europe. (2013). The four main approaches. Retrieved from http://www.alzheimereurope.org/Research/Understanding-dementia-research/Types-of-research/The-fourmain-approaches

Brophy, J. (1998). Failure syndrome students. ERIC Digest. ERIC Clearinghouse on Elementary and Early Childhood Education, Champaign, IL.

Brooks, C. (2015). What is entrepreneurship? Business news daily: Small business solutions and inspirations. Retrieved from http://www.businessnewsdaily.com/2642entrepreneurship.html

Ciaccio, J. (2000). A teacher's chance for immortality. The Education Digest, 65(6), 44-8. WilsonWeb July 16, 2001.

Dambudzo, I. I. (2016). Baseline study for children living with disabilities in DomboramwariEpworth: Challenges for empowerment. International Journal of Social Science and Economic Research, 1(8), 1093-1110. 
Goredema, B. (2018). Indigenous fruits of Zimbabwe. Retrieved from SustainZim. http://sustainzim.org/indigenous-fruits-zimbabwe/

Government of New Brunswick. (2015). What is poverty? Economic and social inclusion corporation. Retrieved from http://www2.gnb.ca/content/gnb/en/departments/esic/overview/content/what_is_poverty. html

International Labour Organization (ILO). (2015). Global employment trends for youth 2013informal, poorly paid and unemployed: The reality of work for most youth in developing countries. Retrieved from http://www.ilo.org/global/research/globalreports/global-employment-trends/youth/2013/lang--en/index.htm

Jaishankar, V., \& Sujatha, L. (2016). A study on problems faced by the street vendors in Tiruchirappalli City. SSRG International Journal of Economics and Management Studies (SSRG-IJEMS), 3(5), 124-127. Retrieved from http://www.internationaljournalssrg.org

Johnson, R. B., \& Christensen, L. (2014). Educational research: Quantitative, qualitative, and mixed approaches, (5th edition). USA, UK: SAGE Publications, Inc.

Leubker, M. (2008). Employment, unemployment and informality in Zimbabwe: Concepts, and data for coherent policy-making. International Labour Organization. Issues Paper No. 32 and Integration Working Paper No. 90.

McCulloch, N., Winters, L. A., \&Cirera, X. (2001). Trade liberalisation and poverty: A handbook. London: Centre for Economic Policy Research.

Neuman, W. L. (2014). Social research methods: Qualitative and quantitative approaches, (7th edition). Edinburgh Gate: Pearson Education Limited.

Roever, R. (2014). Informal economy monitoring study sector report: Street vendors. Cambridge MA, USA: WIEGO.

Rouse (2015). ODL (Open and Distance Learning) Tech target search SQL server. Retrieved from http://searchsqlserver.techtarget.com/definition/ODL

Samukange, T. (2015, July 10). Pictures: Vendors' clothing bales burnt. NewsDay Zimbabwe. Retrieved from https://www.newsday.co.zw/2015/07/pictures-vendors-clothing-balesburnt/

Slavin, R. (1998). Can education reduce social inequity? Educational Leadership, 55, 6-10. WilsonWeb July 16, 2001.

Southern African Development Community. (2018). SADC statistics yearbook 2018: Towards a common future. SADC. Retrieved from https://www.sadc.int/information-services/sadcstatistics

Supplement to the Zimbabwean Government Gazette. (2020 June). Statutory instrument 138 of 2020: Epworth (hawkers and vendors) by-laws, 2020. Harare: Government Printers. 
Tenebe, V. A. (2015). Socio-economic strategies for sustainable development in the global context. Models and strategies for sustainable socio-economic transformation. Paper presented at the International Research Conference 2015 in Zimbabwe, Harare.

The Millennium Development Goals Report. (2014). We can end poverty 2015 Millennium Development Goals. New York: United Nations.

The World Bank. (2017). Goal 1: Eradicate extreme poverty and hunger by 2015. Millennium development goals. The World Bank Group. Retrieved from http://www5.worldbank.org/mdgs/poverty_hunger.html

United Nations. (undated). Poverty eradication. Poverty - social policy and development division. Retrieved from http://undesadspd.org/Poverty.aspx

United Nations Department of Economic and Social Affairs Division for Social Policy and Development. (2014). Promoting empowerment of people in achieving poverty eradication, social integration and full employment integration and full employment and decent work for all. Retrieved fromhttp://www.un.org/esa/socdev/publications/FullSurveyEmpowerment.pdf

United Nations Sustainable Development Goals. (2015). New UN-backed report emphasizes the possible contribution of forests to ending hunger. 17 goals to transform our world. Retrieved from http://www.un.org/sustainabledevelopment/blog/2015/05/forests-key-totackle-climate-change-in-2015/

UNESCO. (2013). Transforming TVET: Building skills for work and life. Technical and Vocational Education and Training (TVET). Third International TVET Congress, Shanghai, China, 13-16 May 2012. Retrieved from https://unevoc.unesco.org/home/Report

Women in Informal Employment: Globalizing and Organizing (WIEGO). (2015). Street vendors: Vital contributors to urban economies. Empowering informal workers, securing informal livelihoods. Retrieved fromhttps://www.newsday.co.zw/2012/11/03/unions-disputezimstat-unemployment-report/ 